Vol. 2, No. 1, April 2020, pp.66-76.

e-ISSN:

2686-5009

Productive

Zakat on

Sharia

Perspective

and

Regulation in

Indonesia

Efri Syamsul Bahri, Prasetio Ariwibowo, Hamzah Robbani

How to cite: Bahri, E. S., Ariwibowo, P., \& Robbani, H. (2020).

Productive Zakat on Sharia Perspective and Regulation in Indonesia. LITERATUS, 2 (1), 66-76. https://doi.org/10.3701 0/lit.v2i1.36

\section{Productive Zakat on Sharia Perspective and Regulation in Indonesia}

\author{
Zakat Produktif dalam Perspektif Syariah dan Peraturan di Indonesia
}

\author{
Efri Syamsul Bahri ${ }^{1)}$ \\ STEI SEBI Depok, Indonesia \\ Jl. Raya Bojongsari, Depok, Indonesia \\ Prasetio Ariwibowo ${ }^{2)}$ \\ Universitas Indraprasta PGRI Jakarta \\ Nangka Raya Street No. 58C, RT 05/05, Jakarta, Indonesia \\ Hamzah Robbani ${ }^{3)}$ \\ Universitas Indraprasta PGRI Jakarta \\ Nangka Raya Street No. 58C, RT 05/05, Jakarta, Indonesia
}

Abstract

This paper describes the review of productive zakat in sharia and regulatory perspectives. This research uses library research methods by reviewing and collecting the results of previous studies that are in line with the theme of this study. The results of this study indicate that productive zakat in sharia perspective is allowed to improve the economic life of the mustahiq and meet the needs in worshiping Allah SWT. While productive zakat from a regulatory perspective in Indonesia is at the macro, meso and micro levels. The authenticity of this study is permissible and productive zakat. A new aspect of this research is conducting a study with two discussions namely the sharia perspective and regulatory perspective in Indonesia.

Keywords: productive zakat, sharia perspective, regulation Abstrak

Artikel ini menjelaskan tinjauan zakat produktif dalam perspektif syariah dan peraturan. Penelitian ini menggunakan metode penelitian kepustakaan dengan mengkaji dan mengumpulkan hasil penelitian sebelumnya yang sesuai dengan tema penelitian ini. Hasil penelitian ini menunjukkan bahwa zakat produktif dalam perspektif syariah diperbolehkan untuk meningkatkan kehidupan ekonomi mustahiq dan memenuhi kebutuhan dalam beribadah kepada Allah SWT. Sementara zakat produktif dari perspektif peraturan di Indonesia berada di level makro, meso, dan mikro. Keaslian penelitian ini diizinkan dan zakat produktif. Aspek baru dari penelitian ini adalah melakukan penelitian dengan dua diskusi yaitu perspektif syariah dan perspektif peraturan di Indonesia.

Kata kunci: zakat produktif, perspektif syariah, peraturan 


\section{INTRODUCTION}

The glorious history of zakat management emerged in the era of Umar bin Abdul Aziz, where zakat ijtihad on income was determined by the caliph and was obligatory (Ahmad Satori Ismail, 2018), making zakat a major source of income for the country (Kuliman, 2014, p. 59), people live in peace(Siradj, 2014, p. 413).At that time(Wardani, 2017 , p. 152), poor people are no longer entitled to receive zakat so zakat is sent to neighboring countries in need.

The development of zakat management in Indonesia shows growth both from the collection aspect and from the distribution aspect. The collection of zakat in Indonesia is carried out by the National Board Zakat (BAZNAS) formed by the government and the Amil Zakat Institution formed by the community and confirmed by the government(Nofiaturrahmah, 2015, pp. 282-283). From both aspects, both collection and distribution continued to experience growth, as shown in Table 1 and Table 2.

Table 1 Total Collection Based on Fund Type (IDR)

\begin{tabular}{|c|c|c|c|c|c|}
\hline No & $\begin{array}{c}\text { Types of } \\
\text { Funds }\end{array}$ & 2016 & $\%$ & 2017 & $\%$ \\
\hline 1 & Zakat & 3.738 .216 .792 .496 & 74,51 & 4.194 .142 .434 .378 & 67,38 \\
\hline 2 & Infak/Sedekah & 1.001.498.305.006 & 19,96 & 1.764.883.196.993 & 28,35 \\
\hline \multirow[t]{2}{*}{3} & Other & & & & \\
\hline & $\begin{array}{l}\text { Religious } \\
\text { Social Funds }\end{array}$ & 277.336.514.452 & 5,53 & 265.345.638.101 & 4,26 \\
\hline \multirow[t]{2}{*}{4} & Other Funds*) & 241.514 .997 & 0 & 0 & 0 \\
\hline & Amount & 5.017 .293 .126 .950 & 100 & 6.224 .371 .269 .472 & 100 \\
\hline
\end{tabular}

Sources: Strategis (2019)

Nationally, the collection of zakat increased from IDR5,017,293,126,950 to IDR6,224,371,279,472 or grew by 24 percent. This is certainly encouraging because it is far above Indonesia's economic growth which reached 5.07 percent (BPS, 2018).

Table 2 Total Distribution Based on Ashnaf (IDR)

\begin{tabular}{llrrrc}
\hline \multirow{2}{*}{ No } & \multicolumn{1}{c}{ Asnaf } & $\begin{array}{c}\text { Amount of Funds } \\
2016\end{array}$ & \multirow{2}{*}{$\begin{array}{c}\text { Amount of Funds } \\
2917\end{array}$} & \multirow{2}{*}{$\%$} \\
\hline $\mathbf{1}$ & Poor Fakir & 2.137 .613 .944 .379 & 72,93 & 3.356 .325 .642 .451 & 69,06 \\
$\mathbf{2}$ & Amil & 209.233 .041 .289 & 7,14 & 518.647 .467 .254 & 10,67 \\
$\mathbf{3}$ & Muallaf & 17.403 .367 .642 & 0,59 & 97.156 .889 .988 & 2,00 \\
$\mathbf{4}$ & Riqob & 4.278 .727 .729 & 0,15 & 21.827 .062 .720 & 0,45 \\
$\mathbf{5}$ & Gharimin & 16.435 .575 .105 & 0,56 & 40.772 .744 .732 & 0,84 \\
$\mathbf{6}$ & Fi Sabilillah & 524.865 .496 .303 & 17,91 & 755.062 .496 .814 & 15,54 \\
$\mathbf{7}$ & Ibnu Sabil & 21.379 .958 .163 & 0,73 & 70.363 .020 .484 & 1,45 \\
\hline \multicolumn{2}{r}{ Amount } & 2.931 .210 .110 .610 & 100 & 4.341 .507 .857 .190 & 100 \\
\hline
\end{tabular}

Source: Baznas (2019)

Distribution of zakat is allocated to 5 (five) Fields of Programs, including: Economic, education, missionary, health and humanitarian fields. The amount of
Literatus is a journal published by

Neolectura, issued two times in one year. Literatus is a scientific publication media in the form of conceptual paper and field research related to social impact and cultural studies. It is hoped that Literatus can become a media for academics and researchers to publish their scientific work and become a reference source for the development of science and knowledge.

Our focus:

Social and Culture

Our Scope:

Humanities

Education,

Management

History,

Economics,

Linguistics,

Literature

Religion,

Politics,

Sociology,

Anthropology, and others. 
Vol. 2, No. 1, April 2020, pp.66-76.

e-ISSN:

2686-5009

Productive

Zakat on

Sharia

Perspective

and

Regulation in

Indonesia

Efri Syamsul Bahri, Prasetio Ariwibowo,

Hamzah Robbani

How to cite:

Bahri, E. S., Ariwibowo,

P., \& Robbani, H. (2020).

Productive Zakat on

Sharia Perspective and Regulation in Indonesia. LITERATUS, 2 (1), 66-76. https://doi.org/10.3701 0/lit.v2i1.36 distribution based on this field is added by not including the allocation for Amil or Operations. The biggest disbursement in 2017 was for the Social Humanitarian Sector at 25.89 percent, followed by the distribution of the Da'wah Field. Distribution of the Economy actually ranked fourth with an achievement of 20.33 percent. This shows that the allocation of zakat for productive zakat is still far compared to the allocation of zakat for consumptive zakat.

Table 3 Total Distribution Based on the Distribution Sector

\begin{tabular}{clrcrc}
\hline No & \multicolumn{1}{c}{ Sector } & $\begin{array}{c}\text { Amount of } \\
\text { Disbursment 2016 }\end{array}$ & \% & $\begin{array}{c}\text { Amount of } \\
\text { Disbursment } \\
\mathbf{2 0 1 7}\end{array}$ & \% \\
\hline $\mathbf{1}$ & Economy & 493.075 .489 .398 & 18,30 & 882.515 .274 .729 & 20,33 \\
$\mathbf{2}$ & Education & 842.980 .341 .134 & 31,28 & 941.865 .099 .137 & 21,69 \\
$\mathbf{3}$ & Islamic Preaching & 418.454 .281 .897 & 15,53 & 979.468 .717 .694 & 22,56 \\
$\mathbf{4}$ & Health & 226.004 .399 .823 & 8,39 & 413.507 .938 .849 & 9,52 \\
$\mathbf{5}$ & Social Humanity & 714.267 .956 .361 & 26,51 & 1.124 .150 .826 .782 & 25,89 \\
\hline & \multicolumn{1}{c}{ Amount } & 2.694 .782 .468 .613 & 100 & 4.341 .507 .857 .190 & 100 \\
\hline
\end{tabular}

Source: Baznas (2019)

In Indonesia, the management of zakat is regulated by Law No. 13 of 2011 Challenging the Management of Zakat. The position of zakat and its management in Indonesia has become very strategic. This can be seen from the wrong purpose of managing national zakat (Bahri, 2020), namely: to increase the effectiveness and efficiency of services in the management of zakat, and increase the benefits of zakat to realize community welfare and poverty reduction. To realize this goal can be done through productive zakat.

Productive zakat (Bahri, 2020) an effective way to alleviate poverty, a model of zakat distribution in solving social problems (Effendi, 2017), with the aim of empowerment to improve the quality of life of mustahik and change status to muzaki (Nasional, 2020), one mechanism in overcoming the problem of poverty (Pratama, 2015), one way to reduce poverty in Islamic societies (Yasir, 2014) and provide a wider impact (Saptia, 2013), a solution for the development of micro-entrepreneurs by providing access to working capital (Oktaviani, 2018), and be a solution to overcome the problem of access to working capital for micro entrepreneurs (Bahri, 2019).

Productive zakat also aims to make mustahik a muzaki (Fitri, 2017), fulfilling the necessities of living worthy of worshiping Allah SWT, avoiding the dangers of infidelity, eliminating envy, envy, and malice, providing adequacy and well-being (Ismail, 2018) and improve welfare (Muslikh, 2016). The issue is how to review productive zakat in both sharia and regulatory perspectives.

Based on the explanation above, the authors are interested in conducting research with the research title Productive Zakat on Sharia Perspective and Regulation in Indonesia. The purpose of this study is to describe how productive zakat reviews are in the perspective of sharia and regulation. The scope of research is productive zakat in Indonesia.

\section{Understanding Zakat}

Zakat is part of the pillars of Islam (Aibak, 2015), a socioeconomic order, whose rule was passed down to the Messenger of Allah (may peace be upon him) in the second year of the Hijrah and continued by the Khulafa'ur-Rashidin (Ismail, 2018).

The position of zakat is obligatory for every person in Islam(Chaniago, 2015, p. 47)who has qualified (Ismail, 2018). Among others: Islam, independence, perfect 
property rights, lawful, developing, reaching nisab / zakat minimum limit except rikaz (not required), more than basic needs, free of debt and haul (one year Qamariyah has passed). Zakat is also a means to carry out social accountability and is obligatory for Muslims (Adzrin, 2015).

According to Syalthut (Ismail, 2018), Zakat is part of the wealth spent by the rich for needy brothers and for public purposes which is a vital need for the community, with the aim (Qardhawi, 2005);(Firmansyah, 2013) to solve various social problems such as: unemployment, poverty, and others. According to Qardhawi (Setiadi, 2016) here are 4 (four) ways to alleviate poverty, namely: by working, guaranteeing relatives, state guarantees and through zakat.

Zakat is intended for relatives in need and for public purposes which are vital needs for the community (Beik, 2019), to empower mustahik in the form of working capital support, work equipment support, business assistance, spiritual assistance, marketing access support and other services (Bahri, 2019).

\section{Productive Zakat}

In its development, there is what is called zakat consumptive and there is productive zakat. In the context of good regulation in Indonesia, productive zakat is included in the distribution program category. Whereas productive zakat is classified into the utilization program. Consumptive zakat is given to mustahik to fulfill daily needs, while productive zakat aims to make mustahik independently become a muzaki (Oktaviani, 2018). For mustahik who are still strong and healthy are given productive zakat (Megawati, 2014).

Productive Zakat is defined as a way (Yasir, 2014) and mechanism (Pratama, 2015) in overcoming the problem of poverty (Bahri, 2019). Asnaini (2008), defines productive zakat as zakat in the form of assets or funds given to the mustahik who are not spent directly on the consumption of certain needs, but are developed and used to help their businesses, so that with these efforts they can meet the necessities of life continuously. So, productive zakat is the giving of zakat which can make the recipients produce something continuously with the zakat assets they receive (Firmansyah, 2013).

Productive Zakat has roles and functions, among others: as a source of funds for poverty alleviation (Atabik, 2015), as working capital (Sartika, 2008), open employment (Rozalindah, 2014), increase income, meet their daily needs (Rozalindah, 2014) and (Atabik, 2015), get a steady income, increase business, develop business and they can set aside their income to save (Sartika, 2008), allocative functions and economic stabilizers (Beik 2009).

According to Imam Shafi'i, An-Nasa'i, and others, if mustahik zakat has the ability to trade, he should be given productive zakat in the form of venture capital that allows him to obtain profits that can meet his basic needs. Likewise, if the person concerned has certain skills, production equipment that can be in accordance with his work can be given him (Zain, 2013);(Firmansyah, 2013).

The use of productive zakat was also practiced in the time of the Messenger of Allah as stated in a Muslim hadith of Salim bin Abdillah bin Umar from his father, that the Messenger of Allah had given him alms and asked him to develop or give back(Ahmad Satori Ismail, 2018).

Productive Zakat (Asnaini, 2008) is not spent directly on consumption, but is developed and used to help businesses mustahik, produce continuously (Firmansyah, 2013), developed to be able to meet the needs of life continuously. Therefore, based on the purpose of its use zakat is divided into consumptive zakat and productive zakat.

Productive zakat and consumptive zakat have similarities, differences, weaknesses and strengths (Ali, 2016). First, productive zakat and consumptive zakat can increase 
Vol. 2, No. 1, April 2020, pp.66-76.

e-ISSN:

2686-5009

\section{Productive}

Zakat on

Sharia

Perspective

and

Regulation in

Indonesia

Efri Syamsul Bahri, Prasetio Ariwibowo,

Hamzah Robbani

How to cite:

Bahri, E. S., Ariwibowo,

P., \& Robbani, H. (2020).

Productive Zakat on

Sharia Perspective and Regulation in Indonesia. LITERATUS, 2 (1), 66-76. https://doi.org/10.3701

0/lit.v2i1.36 welfare while reducing mustahik poverty. However, productive zakat is more capable of reducing poverty compared to consumptive zakat. This is due to productive zakat accompanied by business assistance and religious guidance in accordance with the provisions of Islamic law which play a role in removing mustahik from spiritual poverty.

Second, on productive zakat, the factors that influence poverty reduction are mustahik household income and the work of the head of the household. Whereas in consumptive zakat, the influencing factors are the education of the head of the household and the income of the household mustahik. In this case, the income factor is equally influential both on the distribution of the consumptive and productive zakat models. Both ways of channeling zakat can basically improve welfare while reducing mustahik poverty. However, productive zakat is more able to increase the welfare of mustahik compared to consumptive zakat.

Zakat utilization criteria for productive business (Ahmad Satori Ismail, 2018)among others: have fulfilled sharia provisions, generate economic added value for mustahik, mustahik domiciled in zakat management institutions working area, beneficiaries are individuals or groups that meet the mustahik criteria, provide guidance or assistance to mustahik from amil zakat in the area of mustahik domicile. , productive zakat is given to mustahik who are still strong and healthy(Megawati, 2014).

The basic principles of productive zakat management(Fitri, 2017)among others: the basic needs of mustahik must be fulfilled first, directed to create business unit activities that produce a permanent source of revenue, educate self-reliance, pay attention to the level of mustahik ability, be equipped with technical and management assistance programs, limited program time, there is a guarantor institution if it occurs business failure. Assistance was also emphasized (Sutardi, 2017), so that business activities can run well.

The steps that need to be taken in channeling productive zakat program funds are as follows (Firmansyah, 2013): conduct surveys to see the condition of the place of business, take part in routine mentoring and coaching activities every month, provide business capital assistance during mustahik assistance and guidance activities, direct the rights and obligations as a fostered partner, motivate training and self potential, conduct surveys after the provision of venture capital assistance and business equipment.

\section{Role and Function of Productive Zakat}

Zakat produktif memiliki banyak peran dan fungsi, antara lain: sebagai sumber dana pengentasan kemiskinan (Atabik, 2015), as working capital (Sartika, 2008), open employment (Rozalindah, 2014:248), increase income, meet their daily needs (Rozalindah, 2014: 248) (Atabik, 2015), get a steady income, increase business, develop business and they can set aside their income to save (Sartika, 2008), allocative functions and economic stabilizers (El-Din, 1986); (Beik 2009) in (Firmansyah, 2013).

Distribution of productive zakat is one way to reduce poverty in Islamic societies (Yasir, 2014), to ensure that recipients can earn income and achieve poverty alleviation goals (Ismail, 2017).

\section{Product of Zakat Productivity}

The form of productive zakat is business capital, income distribution, increasing income, making Mustahik a muzaki (Fitri, 2017), fulfilling the necessities of living worthy of worshiping Allah SWT, avoiding the dangers of infidelity, eliminating envy, envy, and malice, providing adequacy and well-being (Ahmad Satori Ismail, 2018), as an Islamic instrument for the distribution of income and wealth, suppresses inequality, one of the mechanisms in overcoming the problem of poverty (Pratama, 2015). 


\section{LITERATUS}

Productive zakat through venture capital has provided benefits to microentrepreneurs, including: an increase in sales turnover (Prahesti, 2017), welfare improvement (Muslikh, 2016). Productive zakat can also be used as working capital, capacity building, guidance and spiritual guidance which will ultimately have an impact on the performance of micro-entrepreneurs (Bahri, 2019).

The success of productive zakat is influenced by various factors including mentoring (Muslikh, 2016) and the amount of funds received mustahik. Experience in Malaysia states that productive zakat can be divided into four categories: business capital assistance, business equipment assistance, business financing and work wages (Ismail, 2017).

The steps in distributing productive zakat are (Firmansyah, 2013) conducting surveys, assistance and guidance and providing business capital assistance (Fitri, 2017). Business capital assistance is expected to increase sales turnover (Prahesti, 2017). The success of productive zakat is influenced by various factors including mentoring (Muslikh, 2016) and the amount of funds received mustahik.

\section{Public Policy}

Policies can be defined as a series of program plans, activities, actions, decisions, attitudes, to act or not act by the parties, as a stage for solving the problems faced (Iskandar, 2012); (Abdullah Ramdhani, 2017, p. 2), the process of interaction that the country has with the people (Parsons, 1997); (Suryono, 2018, p. 98).

According to Thoha (2012); (Abdullah Ramdhani, 2017, p. 2), The policy is divided into two aspects, among others: Policy is a social practice and policy is a response to events that occur, both to create harmony from the parties to the conflict, and create incentives for joint action for parties who get irrational treatment of joint venture.

While public policy (public policy) according(Anggara, 2014, p. 14 dan 24)is a series of choices that are more or less interconnected that includes the stages of policy problem formulation, policy implementation, and policy evaluation, are policies made with the public sphere, which are the joint sphere(Suryono, 2018, p. 98).

Nugroho in Tahir (2011, hal. 48); (Hilman Septiawan, 2019, pp. 355-356) classifying public policy in Indonesia into three levels. First, public policies that are macro or general, or fundamental, namely (a) the 1945 Constitution, (b) Laws / Perpu, (c) Government Regulations, (d) Presidential Regulations, and (e) Regional Regulations. Second, public policies that are (meso) or intermediate, or clarifying the implementer. This policy can take the form of Ministerial Regulations, Ministerial Circular Letters, Governor Regulations, Regents of Regents, and Regulations of Mayors. The policy can also take the form of Joint Decrees or SKB between Ministers, Governors, Regents and Mayors. Third, micro public policies are policies that regulate the implementation or implementation of the above policies. The form of the policy is a regulation issued by public officials under the Ministry, the Regent, and the Mayor.

\section{RESEARCH METHODS}

This research uses library research method by using literature, including handbooks, journals, articles, etc(Bayuseno, 2010, p. 39). Through library studies(Alwidakdo, 2014, p. 14)Obtained information and secondary data related to this research. The purpose of literature study(Anjar Wanto, 2019, p. 39)is to supplement the basic knowledge and theories used in this study.

\section{RESULTS AND DISCUSSION Management of Zakat in Indonesia}

Literatus is a journal published by

Neolectura, issued two times in one year. Literatus is a scientific publication media in the form of conceptual paper and field research related to social impact and cultural studies. It is hoped that Literatus can become a media for academics and researchers to publish their scientific work and become a reference source for the development of science and knowledge.

Our focus:

Social and Culture

Our Scope:

Humanities,

Education,

Management,

History,

Economics,

Linguistics,

Literature,

Religion,

Politics,

Sociology,

Anthropology, and others. 
Vol. 2, No. 1, April 2020, pp.66-76.

e-ISSN:

2686-5009

\section{Productive}

Zakat on

Sharia

Perspective

and

Regulation in

Indonesia

Efri Syamsul Bahri, Prasetio Ariwibowo,

Hamzah Robbani

How to cite:

Bahri, E. S., Ariwibowo,

P., \& Robbani, H. (2020).

Productive Zakat on

Sharia Perspective and Regulation in Indonesia. LITERATUS, 2 (1), 66-76. https://doi.org/10.3701 0/lit.v2i1.36
Management of zakat in Indonesia is carried out by the National Board Zakat (BAZNAS) and the Amil Zakat Institution (LAZ). The National Board Zakat (BAZNAS) is the official and only body formed by the government based on Presidential Decree No. 8 of 2001 which has the duties and functions of collecting and distributing zakat, infaq, and alms (ZIS) at the national level.

BAZNAS is a non-structural government agency that manages zakat nationally in Indonesia(Bahri, 2020, p. 164). Management of zakat in Indonesia is based on sharia and Law No. 23 of 2011 concerning Management of Zakat. The birth of Law Number 23 of 2011 concerning Management of Zakat reinforces the role of BAZNAS as an institution authorized to conduct zakat management nationally.

Whereas LAZ is initiated by civil society with the approval of the appointed minister or official(Firmansyah, 2013, p. 184), initiated by the community(Siradj, 2014, p. 417).LAZ has the main task of assisting BAZNAS in the collection, distribution and utilization of zakat where the process of its formation must obtain permission from the Minister or an official appointed by the Minister(Yandi Bastiar, 2019, p. 45).

\section{Sharia Perspective Productivity Zakat}

Productive distribution of zakat was a common occurrence in the time of the Prophet. Hadith of the Muslim Imam of Salim bin Abdillah bin Umar from his father, that the Prophet had given him alms and asked him to develop it or give it back. (Muslihun, 2014)

In terms of sharia, productive zakat is allowed to improve the economic life of the mustahik(Zalikha, 2016).Zakat utilization criteria for productive business(Ahmad Satori Ismail, 2018)among others: have fulfilled sharia provisions, generate economic added value for mustahik, mustahik domiciled in the zakat management institution working area, the beneficiaries are individuals or groups that meet the mustahik criteria, provide guidance or assistance to mustahik from amil zakat in the area of mustahik domicile.

Another requirement is that the basic needs of the mustahik must be fulfilled first, directed to create business unit activities that produce a permanent source of revenue, educate self-reliance, pay attention to the level of mustahik ability, management principles(Fitri, 2017); (Sutardi, 2017)equipped with technical assistance and management programs, limited program time, there is a guarantor institution in case of business failure, as well as(Megawati, 2014)given to mustahik who are still strong and healthy.

Based on Fatwa Number 4 of 2003 concerning the Use of Zakat Funds for istithmār (investment) there are conditions for the use of zakat allocated for business capital, namely: (1) zakat must be distributed to businesses that are justified by sharia and applicable regulations (al-țuruq al- mashru'ah); (2) invested in business fields that are believed to provide benefits on the basis of a feasibility study; (3) The business must be fostered and supervised by competent parties; (4) The business must be run by professional and trustworthy institutions (institutions); (5) The business capital must be guaranteed by the government and the government must replace it if a loss or bankruptcy occurs; (6) There must be no poor people who are starving or need funds that cannot be postponed when the zakat property is invested; (7) The use of zakat funds for business capital that is terminated due to investment must be limited in time. (Fitri, 2017, p. 165)

Spiritually, productive zakat aims to meet the needs of a decent life and meet the needs in worship to Allah SWT to avoid the danger of kufr, eliminate jealousy, jealousy, and jealousy, and be able to provide sufficiency and prosperity (Ahmad Satori Ismail, 2018); (Muslikh, 2016); (Efri Syamsul Bahri M. M., 2019, p. 262). 


\section{Zakat Productive Regulation Perspective}

Based on the public policy theory described by Nugroho in Tahir (2011, hal. 48); (Hilman Septiawan, 2019, pp. 355-356), which classifies public policy in Indonesia, productive zakat is included in the macro, meso and micro levels. First, the macro level. At the macro level, productive zakat is regulated by Law No.23 of 2011 concerning Management of Zakat, Government Regulation No. and Regional Regulations.

In Law No. 23 of 2011 concerning Management of Zakat in Chapter III article 27 states that zakat can be utilized for productive business in the context of handling the poor and improving the quality of the people. Utilization of zakat for productive business as intended is done if the basic needs of mustahik have been fulfilled. Further provisions regarding the utilization of zakat for productive business are regulated by a Ministerial Regulation.

From the regulatory aspect, it is clearly stated that the utilization is channeled for productive businesses in the framework of handling the poor and improving the quality of the people(Sintha Dwi Wulansari., 2014)which is carried out when the basic needs of the mustahik have been met, utilized for productive efforts to empower the poor and improve the quality of the people(Agus Faisal, 2017), in the framework of handling the poor and improving the quality of the people(Efendi, 2017, p. 26).

Based on the explanation above, it can be concluded that legally, the use of zakat for productive economic activities is also not prohibited. However, it should be noted that this is done as long as the existence of the mustahik who are obliged and must be assisted have met their basic needs. (Fitri, 2017, hal. 149)

Second, meso level. At the meso level, productive zakat is regulated in the Regulation of the Minister of Religion (PMA) of the Republic of Indonesia Number 52 of 2014 concerning Requirements and Procedures for Calculating Zakat Mal and Zakat Fitrah As well as Utilizing Zakat for Productive Business. As amended by Regulation of the Minister of Religion Number 69 of 2015 concerning Amendment to the Regulation of the Minister of Religion Number 52 of 2014 concerning Requirements and Procedures for Calculating Zakat Mal and Zakat Fitrah and Utilization of Zakat for Productive Business (State Gazette of the Republic of Indonesia of 2015 Number 1737). What is meant by productive business is a business that is able to increase income, standard of living, and welfare of the community.

In the PMA it is mentioned that zakat can be utilized for productive efforts in the context of handling the poor and improving the quality of the people. Utilization of zakat for productive business is carried out with 4 (four) conditions, including: (1) If the basic needs of mustahik have been fulfilled; (2) Meet Islamic regulations; (3) Generating economic added value for mustahik; (4) Mustahik is domiciled in the working area of zakat management institutions. Utilization of zakat for productive businesses can be done at least meet the provisions of 2 (two) provisions, namely: a) the beneficiaries are individuals or groups who meet the mustahik criteria; and b. received assistance from Amil Zakat in the mustahik domicile area.

Third, the micro level. At the micro level, productive zakat is regulated in Baznas Regulation No. 3 of 2018 concerning the Distribution and Utilization of Zakat. In this BaznasRegulation the term used for productive zakat is utilization. Utilization is definedas a form of optimal use of Zakat without reducing its value and usefulness in the form of productive endeavors, so that it is useful for achieving public benefit.

Utilization of Zakat is carried out on 3 (three) fields, namely economics, education and health. Utilization of Zakat in the economic field can be provided in the form of assistance aimed at alleviating poverty, increasing productive capacity, entrepreneurship,
Literatus is a journal published by

Neolectura, issued

two times in one

year. Literatus is a

scientific publication media in the form of conceptual paper and field research related to social impact and cultural studies. It is hoped that Literatus can become a media for academics and researchers to publish their scientific work and become a reference source for the development of science and knowledge.

Our focus:

Social and Culture

Our Scope:

Humanities,

Education,

Management,

History,

Economics,

Linguistics,

Literature,

Religion,

Politics,

Sociology,

Anthropology, and others. 
Vol. 2, No. 1, April 2020, pp.66-76.

e-ISSN:

2686-5009

Productive

Zakat on

Sharia

Perspective

and

Regulation in

Indonesia

Efri Syamsul Bahri, Prasetio Ariwibowo,

Hamzah Robbani

How to cite: Bahri, E. S., Ariwibowo, P., \& Robbani, H. (2020).

Productive Zakat on Sharia Perspective and Regulation in Indonesia. LITERATUS, 2 (1), 66-76. https://doi.org/10.3701 0/lit.v2i1.36 increasing the welfare of Mustahik, empowering the Mustahik community on a regional basis and local economic potential.

Utilization of Zakat in the field of education can be given in the form of assistance to improve the competence of life skills, leadership, entrepreneurship, as well as the construction of educational facilities and infrastructure. Utilization of Zakat in the health sector can be provided in the form of promotive and preventive health assistance, as well as the construction of health facilities and infrastructure.

\section{CONCLUSION}

The results of this study indicate that productive zakat in the perspective of productive sharia is allowed to improve the economic life of the mustahik and fulfill the needs of worshiping Allah SWT. The criteria that must be met in distributing productive zakat are compliance with sharia provisions, generating economic added value for mustahik, mustahik domiciled in the zakat management institution work area, beneficiaries are individuals or groups who meet the mustahik criteria, provide guidance or assistance to the mustahik from amil zakat which is in the area of domicile mustahik.

By regulation, the use of zakat for productive economic activities is also not prohibited, as long as the existence of the mustahik who are obligatory and must be assisted have met their basic needs. While productive zakat from the perspective of the level of regulation in Indonesia is at the macro, meso and micro levels. At the macro level, productive zakat is regulated by Law No.13 of 2011 concerning Management of Zakat, Government Regulation No. and Regional Regulations. At the meso level, productive zakat is regulated in the Regulation of the Minister of Religion (PMA) No. about productive zakat. Governor's Regulations, Regents Regulations and Mayor Regulations. Whereas at the micro level, productive zakat is regulated in Baznas Regulation No. 3 of 2018 concerning Distribution and Utilization.

\section{BIBLIOGRAPHY}

Ramdhani, A. (2017). Konsep Umum Pelaksanaan Kebijakan Publik Abdullah. Jurnal Publik, 11(1), 1-12. doi:10.1109/ICMENS.2005.96

Adzrin, R. (2015). Assessing the Satisfaction Level of Zakat Recipients Towards Zakat Management. Procedia Economics and Finance, 31(15), 140-151. doi:10.1016/S2212-5671(15)01141-7

Faisal, I. Y. A. (2017). Productive Zakat of Baznas Yogyakarta on the Growth of Micro Business. Journal of Economics and Business "Shirkah", 2(3). doi:10.22515/shirkah.v2i3.169

Ismail, A. S. (2018). Fikih Zakat Kontekstual Indonsia. Jakarta: BAZNAS.

Aibak, K. (2015). Zakat Dalam Perspektif Maqashid Al-Syariah. AHKAM, 3(3), 199218. doi:10.21274/ahkam.2015.3.2.199-218

Alwidakdo, A. (2014). Studi Pertumbuhan mangrove pada Kegiatan Rehabilitasi Hutan Mangrove di Desa Tanjung Limau Kecamatan Muara Badak Kabupaten Kutai Kartanegara. Jurnal AGRIFOR, 11-18.

Anggara, S. (2014). Kebijakan Publik. Bandung: Pustaka Setia Bandung.

Wanto, A. P. A. (2019). Analisis Prediksi Indeks Harga Konsumen Berdasarkan Kelompok Kesehatan Dengan Menggunakan Metode Backpropagation. Jurnal \& Penelitian Teknik Informatika, 37-44.

Atabik, A. (2015). Peranan Zakat Dalam Pengentasan Kemiskinan. Jurnal Zakat dan Wakaf, 2(2), 340. 


\section{LITERATUS}

Bahri, E. S. (2020). Analisis Efektivitas Penyaluran Zakat pada Badan Amil Zakat Nasional. Al Maal : Journal of Islamic Economics and Banking, $164-175$.

Bayuseno, A. P. (2010). Kajian Pustaka Tentang Keausan Pada Pahat Bubut. Rotasi, 38-41. doi:https://doi.org/10.14710/rotasi.12.2.38-41

BAZNAS, P. (2019). Outlook Zakat Indonesia 2019. Jakarta: Puskas BAZNAS.

Chaniago, S. A. (2015). Pemberdayaan Zakat Dalam Mengentaskan Kemiskinan. Jurnal Hukum Islam, Volume 13, Nomor 1, Juni 2015. Diambil kembali dari e-journal.stain-pekalongan.ac.id/index.php/jhi

Efendi, M. (2017). Pengelolaan Zakat Produktif Berwawasan Kewirausahaan Sosial Dalam Mengentaskan Kemiskinan Di Indonesia. Ilmu Syari'A $h$ Dan Hukum, 21-38.

Bahri, E. S. (2019). Maqasid Al-Shariah in Micro-entrepreneurs Development : an Overview. International Conference of Zakat 2019 (hal. 258-267). Bandung: Puskas BAZNAS dan Universitas Padjadjaran.

Bahri, E. S. (2019). The Role Of Productive Zakat As Working Capital For Micro Entrepreneurs. Proceedings of the 1st Kedah International Zakat Conference 2019 (KEIZAC 2019) (hal. 803). Kedah, Malaysia: Lembaga Zakat Negeri Kedah.

Firmansyah. (2013). Zakat Sebagai Instrumen Pengentasan Kemiskinan dan Kesenjangan Pendapatan. Jurnal Ekonomi dan Pembangunan Vol, Vol 21, No. 2, 179-190.

Fitri, M. (2017). Pengelolaan Zakat Produktif sebagai Instrumen Peningkatan Kesejahteraan Umat. Economica: Jurnal Ekonomi Islam, Volume 8 (Nomor 1), 149-173. doi:http://dx.doi.org/10.21580/economica.2017.8.1.1830

Hilman Septiawan, E. S. (2019). Tinjauan Zakat Perusahaan. Kordinat.

Beik, I. S. (2019). Measurement of Zakat Impact Through Sustainable Livelihood Impact Assessment on Balai Ternak in Tanah Datar. International Conference on Zakat, Tax, Waqf And Economic Development (ZAWED) 2019 MEASUREMENT. Islamic Business School, Universiti Utara Malaysia.

Ismail, I. A. (2017). Productive Zakat Distribution by Zakat Institutions in Malaysia. International Journal of Academic Research in Business and Social Sciences, 7(3), 554-565. doi:10.6007/IJARBSS/v7-i3/2758

Ali, K. M. (2016). Perbandingan Zakat Produktif dan Zakat Konsumtif dalam Meningkatkan Kesejahteraan Mustahik The Comparative Study Between Productive and Consumptive Based Zakat 1 Pendahuluan 2 Tinjauan Pustaka. Jurnal Al-Muzara'ah, 19-32.

Kuliman. (2014). Kebijakan Pengelolaan Keuangan Publik Pada Masa Kekhalifahan Umar Bin Abdul Aziz. Jurnal Ipteks Terapan, 59-66.

Megawati, D. (2014, November ). Evaluasi Program Pemberdayaan Mustahik "Ternak Kambing Etawa Muara Fajar" Pada BAZ Kota Pekanbaru. Pekbis Jurnal, Vol.6(No.3).

Muslihun. (2014). Dinamisasi Hukum Islam di Indonesia pada Zakat Produktif dan Wakaf Produktif: Sebuah Studi Perbandingan. Jurnal al-Manahij, 8(2). doi:https://doi.org/10.24090/mnh.v8i2.408

Muslikh, R. d. (2016). Pengaruh Kualitas Pendamping Terhadap Sikap, Keyakinan Kemampuan, Perilaku Menabung dan Kesejahteraan (Studi Empiris Kelompok Usaha Mandiri LAZ PKPU). Journal of Economics and Business Aseanomics (JEBA).

Nasional, P. K. (2020). KAJI DAMPAK ZAKAT 2019 : Potret Pengelolaan Zakat untuk Menurunkan Tingkat Kemiskinan di Indonesia Wilayah I. Jakarta: Puskas BAZNAS.

Literatus is a journal published by

Neolectura, issued two times in one year. Literatus is a scientific publication media in the form of conceptual paper and field research related to social impact and cultural studies. It is hoped that Literatus can become a media for academics and researchers to publish their scientific work and become a reference source for the development of science and knowledge.

Our focus:

Social and Culture

Our Scope:

Humanities,

Education,

Management,

History,

Economics,

Linguistics,

Literature,

Religion,

Politics,

Sociology,

Anthropology, and others. 
Vol. 2, No. 1, April 2020, pp.66-76.

e-ISSN:

2686-5009

\section{Productive}

Zakat on

Sharia

Perspective

and

Regulation in

Indonesia

Efri Syamsul Bahri, Prasetio Ariwibowo,

Hamzah Robbani

How to cite: Bahri, E. S., Ariwibowo, P., \& Robbani, H. (2020).

Productive Zakat on Sharia Perspective and Regulation in Indonesia. LITERATUS, 2 (1), 66-76. https://doi.org/10.3701 0/lit.v2i1.36
Nofiaturrahmah, F. (2015). Pengumpulan dan Pendayagunaan Zakat Infak dan Sedekah. ZISWAF.

Prahesti, P. P. (2017). Peran Dana Zakat Produktif terhadap Peningkatan Penghasilan Melalui Bantuan Modal Usaha Kecil dan Mikro. Proceeding of Community Development, (hal. 119-134).

Pratama, Y. C. (2015). Peran Zakat Dalam Penanggulangan Kemiskinan. The Journal of Tauhidinomics, 1(1), 93-104.

Oktaviani, R. (2018). Zakat Produktif Sebagai Modal Kerja Usaha Mikro. Perisai, 101120. doi:10.21070/perisai.v2i2.1686

Saptia, Y. (2013, Desember ). Faktor-Faktor Peningkatan Usaha Perempuan Mustahik dalam Berwirausaha. Jurnal Ekonomi dan Pembangunan, Vol 21(No. 2), 191203.

Sartika, M. (2008). Pengaruh Pendayagunaan Zakat Produktif terhadap Pemberdayaan Mustahiq pada LAZ Yayasan Solo Peduli Surakarta. Jurnal Ekonomi Islam La Riba Vol. II, No. 1, Juli 2008.

Setiadi, M. R. (2016). Peran Amil Zakat dalam Mengoptimalkan Zakat Produktif : Studi Analisis Badan Amil Zakat Daerah ( BAZDA ) Kota Bekasi. Maslahah, 7(1), 49-70.

Sintha Dwi Wulansari., A. H. (2014). Analisis Peranan Dana Zakat Produktif Terhadap Perkembangan Usaha Mikro Mustahik ( Penerima Zakat ). Diponegoro Journal of Economics, Volume 3(Nomor 1), 1-15.

Siradj, M. (2014). Jalan Panjang Legislasi Syariat Zakat di Indonesia: Studi terhadap Undang-Undang Nomor 23 tahun 2011 tentang Pengelolaan Zakat. Jurnal Bimas Islam, 7(III).

Strategis, P. K. (2019). Outlook Zakat Indonesia 2019. Jakarta: Strategis, Pusat Kajian. Suryono, A. (2018). Kebijakan Publik untuk Kesejahteraan Rakyat. Jurnal Ilmiah Ilmu Administrasi TRANSPARANSI, 98-102. doi:10.31334/trans.v6i2.33

Sutardi, M. I. (2017, Januari-Juni). Implementasi Kaidah-Kaidah Islam Dalam. $A l$ Masraf: Jurnal Lembaga Keuangan dan Perbankan, Volume 2(Nomor 1), 97109.

Wardani, R. W. (2017). Strategi Komunikasi Badan Amil Zakat Nasional dalam Pengumpulan Zakat Maal. Ilmu Dakwah: Academic Journal for Homiletic Studies, 151-176.

Bastiar, Y. (2019). Model Pengkuran Kinerja Lembaga Zakat di Indonesia. ZISWAF : Jurnal Zakat dan Wakaf, 43-64.

Yasir, M. (2014). Pola Distribusi Zakat Produktif : Pendekatan Maqasid Syari ' ah dan Konsep CSR. Media Syariah, Media Syariah(1), Media Syariah.

Zalikha, S. (2016). Pendistribusian Zakat Produktif Dalam Perspektif Islam. Jurnal Ilmiah Islam Futura, 304.

Zamzami, M. S. (2013). Zakat Dalam Sejarah Umat Pra-Kenabian Muhammad. alIhkâm, 86-99. 